Historic, Archive Document

Do not assume content reflects current scientific knowledge, policies, or practices. 

1931 SPRING CATALOGUE

\section{Rockmont Nursery}

NEW OR NOTEWORTHY PIANTS

Including Mountain Flowers for the Rock Garden

Sliruls, Lovelier Lilacs, Iris, Pl, lox, Seceds

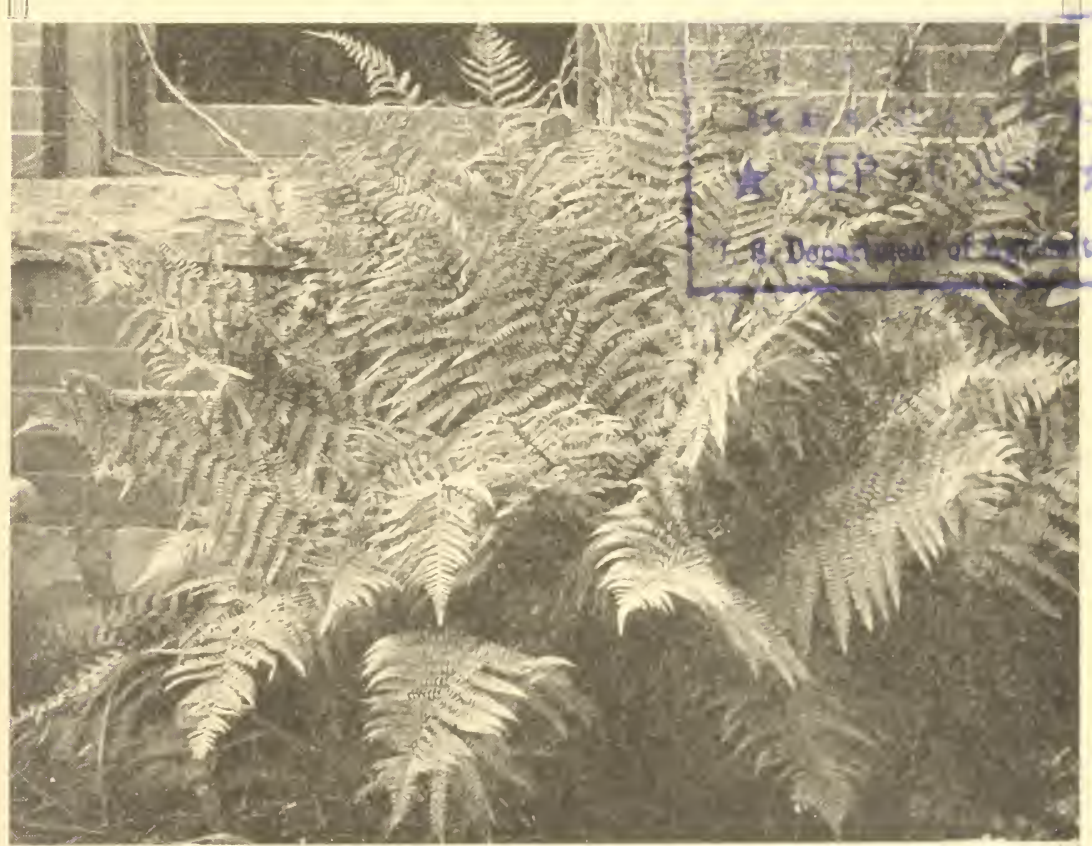

Dryopteris Filix-mas, Colorado Male Fern

D. M. ANDREWS

P. O. BOX 49.5

BOULDER, COLORADO 


\section{Introductory}

Practical Thanks. I know of no better expression of my appreciation of your business than to try to make my service consistently better and more helpful to you.

Time of Delivery. For seeds, any time; the earlier the better. All oul plants are from outdoor stock, and digging can begin in March, continue through April, ending May 1st to May 15th. Orders for Lilacs and other plants that start early, should be placed in time for delivery berore April 15th. It is an advantage to place all orders early; then, in making deliveries, we begin with California and the South, and reach the others all at the most favorable time. This helps to eliminate the rush near the end of the season and gives you better service.

Free Delivery. Plant order's with cash, amounting to $\$ 3.00$ or more, exclusive of seeds, are delivered free. A delivery charge of 25 cents additional is required on orders less than $\$ 3.00$ if wanted by mail. Evergreens and shrubs travel by express at purchaser's expense, care being taken to avoid unnecessary weight.

Safe Delivery is guaranteed by parcel post or express. An immediate report of loss or damage with full particulars is required for adjustment.

Substitution. It is my policy to avoid substitution. Orders taken partly or entirely from an old catalogue are almost certain to include items temporarily out of stock. If you are obliged to use an old catalogue, please do not fail to include a few substitute items that may be used if necessary; otherwise in small matters I wili substitute as closely as possible something of equal or better value.

Cannot Supply. If you have have inquired for plant material or varieties not listed in the latest catalogue, and find this paragraph marked, please understand that such items are not a vailable.

Canadian and Foreign correspondents who receive this catalogue are requested to limit their orders to seeds, remitting cash in full with order.

Garden Clubs. The official of any garden club may apply for four copies of this catalogue for the use of members. These will be furnished so long as a supply is available.

Correspondence is invited with the Trade and with Landscape Architects, who are interested in our New or Noteworthy plants and shrubs.

Address all orders and correspondence to,

D. M. ANDREWS,

P. O. Box 493, Boulder, Colorado. 


\section{Evergreens}

The native evergreens of Colorado are unsurpassed as to hardiness, and at the same time possess unequaled beauty ot" outline and foliage.

My two specialties, the Colorado Blue Spruce and the Colorado Silver Juniper or Cedar are nursery-grown, (not collected) from selected seed to produce the characteristic blue or silvery specimens. The Silver Juniper from our Colorado seed comes uniformly true to color. The Blue Spruce shows more variation. In the sizes up to and including 18 inches no attempt is made at selection, except to eliminate all that are green. The blue and extra blue of the remainder improves and becomes more characteristic as the trees become fully re-established alter transplanting.

This line of medium sizes is recommended, first, because the juvenile period of slow growth is past. Beautiful trees, well rooted, dug with ball and burlapped, may be planted with entire confidence and are ready for comparatively rapid growth. Second, the weight when ready for shipment is not excessive, consequently the cost of transportation is moderate, and a real saving is assured over prevailing retail prices.

Note. Evergreens of the following list under two feet will be crated free provided the order amounts to $\$ 5.00$ or more; add $\$ 1.00$ for cost of crating on orders less than $\$ 5.00$. On lalger sizes the cost of crating is additional.

Juniperus Sabina Tamariscifolia. An excellent dwarf variety of $2-3$ feet, $\$ 5.00 ; 3-4$ feet, $\$ 7.50$ each. Special quotation in quantity.

Juniperus Sabina Tamariscifolia. An excellent dwarf variety for the rockgarden. Very fine specimens, $12-18$ inches, $\$ 3.50$ each, six for $\$ 17.50$. 18-24 inches $\$ 5.00$ each, six for $\$ 25.00$. Measurament is spread and not height.

Juniperus scopulorum Colorado Silver Juniper. Best of the upright growing Junipers, of close columnar habit retaining its silvery color through the winter, and hardy. Rapidly approaching in popularity the Colorado Blue Spruce. 18-24 inches, $\$ 3.00$ each, six for $\$ 15.00 ; 3$-foot trees, $\$ 6.00$ each; 4 -foot trees, $\$ 8.00$ each.

Picea pungens glauca. Colorado Blue Spruce. Fine little trees, 10 to 12 inches, $\$ 2.00$ each, six for $\$ 10.00 ; 12-18$ inches, $\$ 3.00$ each, six for $\$ 15.00 ; 18-24$ inches, $\$ 4.50$ each, six for $\$ 22.50$. Extra heavy blue specimens, 2 feet and over, at $\$ 5.00$ per foot.

Pinus edulis. Pinon or Nut Pine. Slow-growing dwarf pine for a dry position. 8-12 inches, \$3.50 each. 


\section{Lovelier Lilacs}

"Own-root' Lilac bushes growing and flowering on their own roots are everywhere conceeded to be the best. Grafting or budding on Privet is a quick way to produce increase of stock, but unless closely watched the bushes will grow up to sprouts from below the graft, or fail in vigor because of an inadequate root-system. For long-lived bushes with a perfect rootsystem, plant own-root lilacs from Rockmont Nursery.

The size of bushes will average two to three feet tall, unless otherwise indicated. "Small plants" will be less than two feet but well established stock. "Large bushes" are three to four feet tall or larger, and are exceptionally fine stock and heavily rooted.

Not prepaid. Lilacs must be shipped by express. Excessive weight is avoided in packing to insure economical transportation. Lilacs should be delivered in spring before growth commences. Place your order early enough for shipment before April 15th. Autumn delivery begins about October 20th and continues through November.

List of varieties. Own-root stock exclusively. Extreme care is exercised to have every plant true to name; I will replace or refund amount paid for any that proves untrue. Safe delivery guaranteed. All are double unless described otherwise.

Alba Grandiflora. A tall-growing single white with large panicles. Small bushes, $\$ 2.00$ each.

Alphonse Lavalle. Lilac-blue, large full truss, medium dwarf. $\$ 2.00$ each.

Charles Joly. Dark crimson-purple, long narrow panicle, vigorous upright habit, very free, one of the best dark varieties. $\$ 1.50$ each; large bushes, $\$ 2.00$.

Congo. Single; very large broad panicle, bright red-purple, profuse bloomer. One of the most valuable, regardless of price. $\$ 2.50$ each; small bushes, $\$ 2.00$.

Edouard Andre. Clear mauve pink, buds rose pink, dwarf habit, free flowering, very beautiful. Small, $\$ 2.00$ each.

Emile Lemoine. Pale persian-lilac color with pink-lilac buds, very distinct color, extra bloomer, late. $\$ 2.00$ each; large, $\$ 2.50$.

Frau Bertha Dammann. Single, pure white, early. $\$ 1.50$ each.

Hugo Koster. Single, early, large full truss of bluish violet, dwarf. Small, $\$ 2.00$ each.

Ludwig Spath. Single, very rich dark purple, very long panicle of large flowers. $\$ 1.50$ each; large, $\$ 2.00$.

Maximowiczi. Double, midseason, panicle held well above the foliage. Large duplex floret in well proportioned truss; bluish lavender with purplish buds. $\$ 2.50$ each.

Mme. Casimir Perier. Large creamy white, very free blooming. $\$ 1.50$ each; large, $\$ 2.00$. 
Mme. Lemoine. A very fine pure white, large flower and truss, very double, early. A better grower, and produces finer panicles than Ellen Willmott. $\$ 1.50$ each; large, $\$ 2.00$.

Marie LeGraye. Single, free blooming early white; one of the best of the older varieties. Small bushes, $\$ 1.50$.

President Grevy. Very handsome soft blue-lilac flowers of large size, very double; panicle on established bushes nearly a foot long. \$1.50 each; large, $\$ 2.00$.

Princess Alexandra. Single, midseason, white; a good grower and free bloomer. Small, $\$ 1.50$ each.

Rene Jary des Loges. Large panicle of light bluish mauve; dwarf habit, $\$ 2.00$.

Senator Volland. Double; one of the darker varieties described by a French grower as fuchsia-red. Small, \$1.50.

Virginite. Clear mauve-pink, fine large truss. $\$ 2.00$ each; large, $\$ 2.50$.

Viviand Morel. Large elongated truss, flowers large, double, clear bluish lilac, the buds purple. A vigorous grower and profuse bloomer. $\$ 1.50$ each; large, $\$ 2.00$.

Waldeck Rosseau. Double, rather dwarf, late, iragrant; flowers in large trusses, lilac-rose with paler center; choice variety. Small, $\$ 2.00$.

The Lilac species make handsome bushes, and while the flowers are not as showy as the hybrids, several of them bloom much later and therefore extend the flowering season several weeks. The four species are all own-rooted stock.

Syringa japonica. Japanese Tree Lilac. A handsome small tree, valuable for its late blooming season. Flowers pure white panicle sometimes a foot in height. Exceptionally fine own-root bushes, can be trimmed to single stem; 4 feet tall. $\$ 2.50$ each.

Syringa Josikaea. Hungarian Lilac. Large stout shrub, flowering in June. Foliage glossy, dark green; $\$ 1.00$.

Syringa persica. Persian Lilac. Small slırub to 6 feet, with slender branches and giaceful habit. A very profuse bloomer in May; 75 cents each.

Syringa villosa. Late Lilac. Of dense, bushy habit, valued as a specimen shrub and for its late and propuse flowering; $\$ 1.00$. 


\section{New or Noteworthy Shrubs}

\section{Including Miniature Shrubs}

It is possible now to put an entirely new accent into your planting effects by making a free use of western native shrubs from the highlands and valleys of the central Rocky Mountains. These shrubs are hardy to South Dakota, Michigan and the colder parts of New England, and except as specifically stated, will thrive under ordinary garden conditions. A few, recommended for dry conditions, should not be subjected to an excess of moisture or poor drainage.

Most of the following list are native shrubs. A few, equally hardy, are included from other sources. The size indicated follow. ing the name is the approximate size at maturity.

The stock offered is nursery-grown, and well rooted. Where no size is indicated, a 2-year grade, about 2-3 feet in height, is to be understood. Small, indicates two feet or less; large, 3-4 feet or more. This system of grading does not apply to "Miniature Shrubs" although corresponding in age.

Not Prepaid. Shrubs are not priced prepaid. Light but efficient packing makes for low transportation cost, which is to be paid by purchaser.

Acer ginnala. Shrub to 15 feet. Graceful Maple with the fruits usually red and conspicuous in summer and foliage turning red in autumn. Large, $\$ 1.00$; three for $\$ 2.50$.

Alnus tenuifolia. Mountain Alder. Small tree to 25 feet. Shrublike tree with slender branches and rather upright habit. 4 feet, $\$ 1.00$ each, three for $\$ 2.50$.

Amorpha angustifolia. Western Indigo-bush. 8 feet. For wet or dry position, a resistant shrub of good habit, small pinnate foliage and spikes of brown-purple flowers. 75 cents each, $\$ 7.50$ per dozen.

Amorpha canescens. Lead Plant, 20 inches. The low wandlike stems are furnished with silvery pinnate foliage and terminate in an ample spray of small violet-blue flowers. The color effect is charming and the foliage always attractive; 75 cents each, $\$ 7.50$ per dozen.

Amorpha nana. Dwarf Indigo. 20 inches. A much branched little shrub, with very dark green foliage of minute leaflets and fern-like texture. Each branch carries several spikelets of garnet florets. and the brown seeds which follow are attractive. The whole plant is pleasantly aromatic. Small 75 cents each, $\$ 7.50$ per dozen.

Ampelopsis Saint Paulii. (Parthenocissus) St. Paul Creeper. The best-clinging of the various five-leaved creepers by reason of its many-disced tendrils and also aerial rootlets. Foliage turning deep scarlet or crimson in autumn. Strong plants. 75 cents each, $\$ 7.50$ per dozen.

Betula fontinalis. Rocky Mountain Birch. Small shrubby tree, forming clumps, 12 feet or sometimes larger, for stream banks 
or drier positions. Good foliage and dark redish-brown branches. Large, 75 cents; 4-5 feet, $\$ 1.00$ each, three for \$2.50.

Betula glandulosa. Dwarf Birch. 36 inches. Grows rather slowly, and in a dry position will not outgrow the rock garden for many years. A bush of rounded form, redish-brown twigs, excellent foliage and easily grown. Small busliy clumps, \$1.00) each, three for $\$ 2.50$.

Caragana aurantiaca. Dwarf Pea-Shrub. 24 inches. Buslyy and spreading with very showy orange blossoms and minute dark green leaves. A slow-growing diminutive slurub for a limited space, and thrives in a dry sumny position. My 5-year-old manybranched clumps are 15 to 18 inches tall and are ready for immediate effect. Very bushy, $\$ 1.00$ each, three for $\$ 2.50$; smaller plants, $\$ 5.00$ per dozen.

Caragana chamlagu. Mongolian Pea-Slrub. 36 inches. Small enough for the rock garden and suited to dry conditions. Handsome dark pinnate foliage and showy yellow-red blossoms. Dis tinct from other Pea-shrubs and extremely rare in cultivation. $\$ 1.50$ each.

Clematis ligusticifolia. Western Virgin's Bower. Vine, with pinnate foliage, the showy white flowers in July or August followed by large plumose seed clusters. 75 cents each, three for $\$ 1.50$.

Cornus stolonifera Coloradensis. Colorado Dogwood. 6 feet. A compact rounded bush, the foliage assuming brilliant autumn colors, and the twigs in winter a deep blood-red. Flowering and fruiting nearly all summer with showy clusters of pearl-white berries. 75 cents, $\$ 7.50$ per dozen; per hundred, $\$ 40.00$.

Crataegus erythropoda. Chocolate Thorn. 10 feet. A symmetrical small tree with glossy foliage and chocolate-red fruit. 75 cents each, $\$ 7.50$ per dozen.

Crataegus oxyacantha. English Hawthorn. Small tree to 15 feet with very handsome foliage, fruit scarlet. 75 cents, three for $\$ 2.00$.

Crataegus rivularis. Black Thorn. Fine symmetrical tree to 10 feet, foliage very glossy, fruit black, in clusters; one of the nost beautiful of all hawthorns. 4-6 feet, $\$ 1.50$ each, $\$ 15.00$ per dozen.

Euonymus atropurpureus. Wahoo. 6 feet. This is stock from the extreme nonrth and fruit abundantly. In the matter of fruiting it is the best strain 1 have seen; 75 cents each.

Euonymus radicans colorata. The red and bronze autumn and winter foliage colors are very beautiful. A fine thing for the rockgarden. Small clumps 75 cents.

Euonymus radicans vegatus. Winter Creeper. A very valuable evergreen trailer or climber and hardy where English Ivy does not winter well. Strong 3-year clumps, 75 cents, $\$ 7.50$ per dozen.

Forestiera Neomexicana. Mountain Privet. 10 feet. An erect shrub of the Privet family, leaves small dark green. Recommended as an ornnamental specimen shrub and as a hedge plant. Large, 75 cents, $\$ 7.50$ per dozen. 
Forsythia suspensa Sieboldii. Trailing Golden-bell. Trailing slirub with very slender branches. May be used as a climber and is very effective for hanging over rocks or retaining wall. 75 cents each, $\$ 7.50$ per dozen.

Holodiscus microphyllus. Mountain Spray. 36 inches. Very erect shrub for miniature tree effect, a slow growing member of the Spiraea group, producing creamy sprays of minute flowers in early summer. Dry well drained sunny position. 75 cents each.

Jamesia Americana. Wild Mockorange. A handsome shrub of moderate growth with velvety foliage and clusters of waxywhite fragrant flowers. Best in a well-drained humus soil with partial shade. Each, $\$ 1.00$, three for $\$ 2.50$.

Lonicera Kerolkowii floribunda. Blue-leaf honeysuckle. 8 feet. A spreading bush characterized by blue-green foliage and rosepink flowers, a beauitful color effect. Large, $\$ 1.00$ each.

Lonicera sempervirens. Trumpet Honeysuckle. An American all-summer-flowering vine, the scarlet trumpets are the joy of humming birds and the red berries last all the season. One of our hardiest and best woody climbers. 75 cents each, $\$ 7.50$ per dozen.

Lonicera tatarica grandiflora. White Tartarian H. 6 feet. A fine upright shrub with glaucus foliage and a wealth of large flowers of crystal-white; berries red. 75 cents each, $\$ 7.50$ per dozen.

Lonicera tatarica splendens. Pink Tatarian H. 8 feet. Somewhat larger and more spreading, with rosy pink flowers of exceptionally large size, followed by red berries. 75 cents each, $\$ 7.50$ per dozen.

Lonicera Thibetica. Honeysuckle. A dense much branched shrub suitable for the large rockery. Foliage glossy, dark green above, pale beneath, flowers purple, fruit red. With its small leaves and slender reclining branches it is a distinct shrub of refined appearance, easy to grow and not often met with. 75 cents each, $\$ 7.50$ per dozen.

Lycium pallidum. Bush Matrimony. 30 inches. Very hardy miniature shrub, adapted to a dry, sunny position. Foliage pale gray-green, flowers of conspicuous size, also green, with a tinge of purple. By far the most showy species in fruit which is orangescarlet in color. I have observed no suckering, so prevalent with other species. Bushes 18-24 inches, $\$ 1.50$ each.

Malus floribunda. Japanese flowering Crab. Small tree bearing a multitude of deep rose-red buds and flowers, followed by berry-like fruits. 75 cents each, $\$ 7.50$ per dozen.

Malus Scheideckeri. Hybrid Crab. (Seeding stock.) As this is a hybrid, the seedlings will show variation, but all will be beautiful. 75 cents each, $\$ 7.50$ per dozen.

Philadelphus pubescens. Mock-orange. Large shrub to 8 feet with dark green leaves of thick substance, and large white flowers. Large, 75 cents. 
Philadelphus virginal. Mock-orange. Semi-louble while flowers of largest size. Of highest merit among flowering shrubs. 75 cents each.

Physocarpus opulifolius nanus. 5 feet. Eerect bush with slender branches, leaves small, dark green, a profuse bloomer. is cents each, $\$ 7.50$ per dozen.

Potentilla fruiticosa. Clinquefoil. A variable dwarf shrub of northern latitudes. The Colorado form is semiprostrate, a free and quite continuous bloomer and will thrive in dry soil; by far the best type for the rock garden; 75 cents each, $\$ 7.50$ per dozen.

Prunus Besseyi. Western Sand Cherry, 4 feet. A low spreading bush, extremely profuse in flower and fruit, the cherries being black, of large size and only slightly astringent when fully: ripe. 75 cents each, $\$ 7.50$ per dozen.

Prunus glandulosa sirensis. Pink Flowering Almond. Ownroot stock, grown from cuttings; vastly superior to grafted bushes. $\$ 1.00$ each, three for $\$ 2.50$.

Prunus gracilis. Pigmy Plum. 30 inch. Trained as a miniature tree it will bear the little red plums when little more than a foot in height. 75 cents each.

Prunus melanocarpa. Mountain Choke Cherry. Shrub to 10 feet, forming thickets. Grown from a yellow-fruited strain, and while most of the plants will produce black fruit, a few will have yellow or bright red cherries in racemose clusters. $\$ 1.00$ each.

Rhus cismontana. Rockmont Sumac. 4 feet. A selected type that differs in its dwarfer habit, its small red fruit cluster's and very dark, glossy foliage. Foliage brilliant red in autumn. A shrub of exceptional value. 75 cents, $\$ 7.50$ per dozen.

Rhus cismontana flavescens. Yellow-fruited Sumac. 6 feet. An albino form of the western Sumac with yellow fruit and the leaves yellow in autumn. 75 cents each $\$ 7.50$ per dozen.

Rhus cognata. Durango Sumac. An upright bushy shrub to 8 feet with aromatic tribolate foliage and brilliant red berries in showy terminal clusters. Best in a sunny, dry or well drained position. 75 cents each, $\$ 7.50$ per dozen.

Rhus trilobata. Three-leaved Sumac. 4 feet. A rather low spreading shrub for dry position. Foliage dark green, of thick texture, with which the scarlet fruit makes a vivid contrast. $\$ 1.00$ each.

Robinia hispida. Rose Acacia. 4 feet. A handsome flowering shrub with large rose-colored pea blossoms. Like other Robinias, it spreads by suckers. Large, $\$ 1.00$ each.

Robinia luxurians. Pink Locust. Formerly listed as R. Neomexicana. A small tree, very hardy, the fragrant pink flowers in great profusion through early summer. Plant where the suckers will not be objectionable. 4-6 feet, $\$ 1.00$ each. 
Rosa foliolosa. Pixy Rose. A diminutive Texas species with white flowers, the foliage of dark green narrow leaflets. Distinct from other roses, its neat appearance ,non-weedy habit and very small size characterize it as a gem for the rock garden. Each, 75c; $\$ 7.50$ per dozen.

Rosa lucida alba. (R. virginiana alba.) White Virginia Rose. 4 feet. Single blossoms of pure white, green stems and yellow foliage in autumn; rare and choice. 75 cents each, $\$ 7.50$ per dozen.

Rosa lucida inermis. Thornless V. Rose. 5 feet. Entirely free of thorns, a desirable bush rose with red twigs in winter. 75 cents each, $\$ 7.50$ per dozen.

Rosa melina. Black Canyon Rose. 4 feet. Forms compact clumps which do not spread from the root. Flowers single, dark rose with spicy fragrance. A very choice shrub. $\$ 1.00$ each.

(Rosa stellata. Desert Rose. In appearance, very unique; profusely branching, the twigs are spiny and coated with a felt of stellate hairs. Flowers deep rose, followed by purplish bur-like fruits, the leaves minute, five-parted and dark green. Hardy, and blooms through a long season; a dry, sunny position is recommended. Each $\$ 1.00$.

Rubus deliciosus. Rocky Mountain Bramble or Thimbleberry. 5 feet. One of the finest of Colorado Shrubs, satisfactory and reliable. It is thornless, forms handsome clumps with prettily lobed foliage and in June bears a profusion of snow-white flowers as large as single roses and like them in form. A very fine stock of young transplanted bushes. 75 cents each, $\$ 7.50$ per dozen.

Shepherdia argentea. Buffalo Berry. 8 feet. A tall hardy shrub withstanding extremes of cold and drouth. Its silver-gray foliage is excellent for contrast and the scarlet berries add a touch of color in late summer and autumn. 75 cents each, $\$ 7.50$ per dozen.

Symphoricarpos occidentalis. Wolfberry. 2 feet. A valuable low shrub for dry or rocky slopes with good foliage and clusters of pearly-white berries. 75 cents each.

Symphoricarpos Utahensis. Utah Snowberry. 6 feet. The tallest of the group; excellent foliage, pink flowers and white berries, graceful habit. Large, $\$ 1.00$ each, three for $\$ 2.50$.

Symphoricarpos vaccinioides. Small-leaved Snowberry. An elegant miniature of the Snowberry, of light graceful habit and attractive appearance. Each 75 cents.

Symphoricarpos vulgaris elongata. A selected type of the Coralberry with elongated racemes of berries that are of exceptionally fine color. 75 cents, $\$ 7.50$ per dozen.

Symphoricarpos vulgaris leucocarpa. A beautiful albino with creamy-white berries and light green foliage; excellent for contrast. 75 cents, $\$ 7.50$ per dozen. 


\title{
New or Noteworthy Plants
}

\author{
Including Colorado Mountain Flowers
}

The opportunity to enrich your rockgarden with colorado Mountain Flowers is made the more attractive because of the moderate cost and liberal service. The following are adapted to spring planting. Additional kinds will be included in the autumn catalogue that commence growth too early for spring planting. The height of varieties too tall for the rockgarden is indicated in the descriptions.

The prices of this section include prepaid delivery by parcel post on orders of $\$ 3.00$ or more. Safe delivery guaranteed: for details, see introduction.

Allium brevistylum. Alpine Flowering Onion. Erect umbels of showy deep rose flowers on stems a foot tall. From the subalpine slopes of the Medicine Bow Mountains in moist humus soil. The flowers are quite large, brilliant in color and several weeks earlier than the Pagosa Onion. Easily glown. Clumps, 3-5 pips, 75 cents.

Allium recurvatum superbum. Pagosa Flowering-Onion. Larger every way than the type. The umbels gracefully poised on tall arching stems, and the flower's bright rose-pink. Sold out; new supply in autumn.

Anchusa Myostidif!ora. Entirely distinct, growing but 10 to 12 inches high and as broad with sprays of clear blue Forgetme-not-like flowers in April and May; half-shade. 50 cents each. $\$ 4.00$ per dozen.

Anemone patens Nuttalliana. American Pasqueflower. Silky buds expand with the first few days of spling, into flowers of pale lilac, as large as Crocus. No other flower of Eastel time is more beautiful. Three for 50 cents, $\$ 2.00$ pel dozen.

Aquilegia coerulea. Rocky Mountain Columbine. A marvel among Columbines, four-inch blossoms of blue and white with long slender spurs. Large size and purity of color are assured by planting our true native stock; extra heavy roots, 3 for $\$ 1.00$.

Aquilegia hybrida, Rainbow Blend. Rainbow Columbine. An unsurpassed strain in habit, vigol of growth, length of spur and size of flower. It surpasses all other strains in variety and brilliancy of coloring. in the predominance of colorful shades of pink and rose, scarlet, velvety reds and purples, including tints heretofore unknown. A steady improvement has been made by introducing into the strain size from our own $\mathrm{A}$. coerulea, and intensity of color that will surprise the most experienced grower's. Thrifty young roots, six for $\$ 1.00,25$ for $\$ 3.00$. Seed, $\$ 1.00$ per $1 / 4$ ounce.

Aruncus sylvester. (Spiraea aruncus) Goatsbeard. Erect branching herb, 4 feet. Foliage beautifully cut, the small creamywhite flowers in huge feathery panicles. Very valuable border perennial; each, 50 cents; three for $\$ 1.25$. 
Aster Canbyi. Pink Aster. A low-growing sub-alpine, 8-10 inches, the flowers quite large, in May or June, bright rosy pink to lilac, the pink shades predominating. Easily grown in a peaty soil in full sun. Clumps $\$ 1.00$ each.

Aster frondeus. A dwarf, early species with very large flowers of bluish lavender. A very easily-grown sub-alpine, flowering in May or June. Clumps 75 cents.

Astilbe hybrids, in the following named varieties, supplied in strong field-grown plants at 50 cents per clump in any quantity or in any assortment. Gloria, Gruno, Thunbergii and White Pearl.

Caltha rotundifolia. White Mashmarigold. The two-inch white flowers appear in early spring among the rounded basal leaves of dark green. At home in boggy meadows, it will thrive in half-shade if well supplied with moisture during the growing season. Clumps of $3-5$ buds, 50 cents, $\$ 4.00$ per dozen.

Campanula petiolata. Western Harebell. The Colorado Harebell is distinct from the eastern form in its stronger and more floriferous habit, the exquisite bells of blue in utmost profusion for a long season; a satisfactory and valuable rockplant. Three for 75 cents, $\$ 3.00$ per dozen.

Centaurea rigidfolia. A rare oriental species growing three feet tall with crimson heads for many weeks in summer and autumn; lacks the coarseness of most species. Each 50 cents, $\$ 4.00$ per dozen.

Chionophila Jamesii. Snow-lover. A pretty alpine of fairly easy culture in acid peaty soil with half shade. Like a miniature Pentstemon with a spike of tubular white flowers. Three for 75 cents.

Clematis Davidiana. Tubular flowers of clear blue in whorls from the two-foot erect stems; fragrant; valuable bush type; 50 cents each, $\$ 5.00$ per dozen.

Clematis eriophora. (Silky Clematis.) Bushy species a foot tall with silky foliage and deep purple bell-shaped flowers in May. Clumps 50 cents. $\$ 5.00$ per dozen.

Clematis Fremonti. Fremont's Leather-flower. Less than a foot tall, bushy, with flower bells in shades of lavender and violet, leaves oval with entire margins; very distinct species of easiest culture. 75 cents each.

Clematis integrifolia. Low bush, flowering for a long succession, the handsome blue flowers having petals two inches in length. A most valuable and satisfactory plant. Clumps 50 cents, $\$ 4.00$ per dozen.

Clematis recta grandiflora. A non-climbing species of the habit and appearance of C. recta, having flowers fully two inches across. These appear for a long season in large terminal panicles, are fragrant, pure white, on stems two feet tall. Perfectly hardy, a good thrifty grower and one of the most valuable of bushy varieties. Strong flowering plants, 50 cents each; $\$ 4.00$ a dozen.

Clematis Scotti, Scott's Leatherflower. A foot or two tall, glaucus pinnate foliage, flowers urn-shaped the tips scarcely spreading, large, bluish-violet, beautiful and distinct. Strong roots 50 cents, $\$ 4.00$ per dozen. 
Clematis Simsii, Sims' Leatherflower. Handsome, vigorous climber with herbaceous stems, producing all summer its dark purple bells and silky seed clusters; Texas. Very heavy roots, 75 cents each.

Clematis Texensis, (C. coccinea). Scarlet Leatlerflower. A hardy herbaceous climber which starts from the ground earh season, grows rapialy and blooms constantly from June till frost. The flowers are broadly urn-shaped, brilliant scarlet, and are followed by the silky seed plumes; hardy and exceptionally valuable. 50 cents each, $\$ 5.00$ per dozen.

Convallaria majalis. (Parsons' Var.) Lily of the Valley. A stout garden type with extra large bells on long stems, followed by showy scarlet fruit. Clumps, 50 cents, $\$ 5.00$ pel dozen.

Delphinium Geyeri. Geyer Larkspur. Very showy flower of the foothills with grayish foliage and long spikes of most intense blue flowers in June. Easily cultivated; suitable for dry ground, non-acid soil. Three for 75 cents, $\$ 3.00$ per dozen.

Dictamnus fraxinella. Gas plant. Very showy but infrequent border perennial forming a bush two feet tall; aromatic foliage and spikes of orchid-pink flowers in June. Best in a moderately heavy soil and open sunny position where it will thrive if undisturbed a score of years. Clumps, 50 cents, young plants, \$.?.00 per dozen.

Dodecatheon meadia, Shooting Star. One of the most charming and least known of American natives. Often more than two feet tall, the umbels bearing 20 to 30 white, pink or rose Cyclamen-like flowers of exquisite beauty. All species thrive in rich humus soil in part shade. Three for 50 cents, $\$ 2.00$ per dozen.

Dodecatheon multiflorum. Sub-alpine Shooting Star. From moist sub-aipine meadows its showy umbels of brilliant rosepink and ease of culture put it in first rank among a dozen western species. Not new, but deserving the highest popularity. Light shade, or open sun, with ample moisture during the growing season. Clumps of 5-8 pips, 75 cents.

Dryopteris Felix-mas (Syn. Aspidium Felix-mas.) The (nlorado Male Fern grows in partly shaded situations in the mountains which are either dry or quite moist, a rich humus soil preferred. The large fronds form a vase-like cluster about the crown and are of durable texture and nearly evergreen. It retains, therefore, its splendid appearance throughout the season and is so easily grown that it has come to be the universal favorite for Colorado gardens, succeeding wherever ferns can thrive. Established clumps with fiberous roots, 50 cents each, $\$ 4.00$ per dozen; extra heavy clumps $\$ 1.00$ each, $\$ 10.00$ per dozen.

Erigeron Coulteri. Wolf Creek Daisy. Our selected type forms neat clumps about ten inches tall and the large whiterayed blossoms with yellow centers come in June. Easily grown in the open garden. Clumps, 50 cents, $\$ 4.00$ per dozen.

Erigeron salsuginosus, Sub-alpine Daisy. The most charming of this varied family, stems a foot tall with 2-inch flower heads composed of rather broad rays of rosy-violet with yellow centers; moist soil, partial shade. Clumps, 50 cents, $\$ 4.00$ per dozen. 
Gentiana Andrewsii. Closed Gentian. Most of the Gentians are difficult to establish, but this transplants easily, and the large pale blue bud-like blossoms in September are very beautiful. 50 cents each, three for $\$ 1.00$.

Gentiana Bigelovii. Bigelow's Gentian. Small blue flowers in clusters; dry north slopes. Strong roots. Three for $\$ 1.00 ; 50$ cents each.

Gentiana Parryi. Parry's Blue Gentian. Large showy flowers of deepest blue, clustered, on stems a foot or more tall; moist shaded position. Strong roots, 50 cents, three for $\$ 1.00$.

Geranium nervosum. White Cranesbill. A neat species of profuse flowering habit, blossoms white with thread-veins of violet. The clumps have a spread of 18 inches. An improvement over G. Richardsoni offered previously. Three for $\$ 1.00,50$ cents each.

Geum ciliatum. Western Rosy Avens. A little gem of early spring with rosy-pink flowers followed by tinted seed plumes. Three for 75 cents, $\$ 3.00$ per dozen.

Helianthella quinquenervis. Sunwort. An early-flowering Composite with tall slender stems and large yellow-rayed flowers. Clump, 50 cents.

Iris Missouriensis. The native iris or flag of meadows and mountain valleys, usually wet till after the flowering season in May, later become very dry. A foot tall, forming large clumps, the lavender or pale blue flowers comparatively large and showy. Clump, 75 cents.

Iris Missouriensis Bluebird. Similar to the type, but flowers Bradley's violet, falls veined lighter. Clump, $\$ 1.00$.

Iris Missouriensis Snowbird. Pure white without veining. $\$ 1.50$ each, 10 for $\$ 12.50$.

Leucocrinum montanum. Sandlily or Starlily. Very early spring flower of crystal-white, the size of crocus, from a rosette of narrow foliage. One clump will often bear fifty blooms in one season. Hardy and successful East. Small clumps, 50 cents, $\$ 4.00$ a dozen.

Lewisia pygmaea. Least Bitter-root. A small alpine with deep rose-pink flowers in a rosette of narrow foliage from a thick root. Clumps, 3-5 buds, 75 cents.

Lewisia rediviva. Bitter-root. The state flower of Montana. Elegant rockplant for a warm sunny slope or crevice in soil of turfy loam and gravel. Flowers two inches or more broad, composed of many narrow petals, the pink or white stars arising from a rosette of succulent foliage which disappears at flowering time; northern stock which is entirely hardy, but requires good drainage. Three for 75 cents, 10 for $\$ 2.00$.

Liatris ligulistylis. Rocky Mountain Gayfeather. A dwarf early species with very showy heads of rosy purple. Three for 75 cents, $\$ 3.00$ per dozen.

Liatris punctata. Dotted Gayfeather. Suitable for the dry rockery, several slender spikes less than a foot tall. Three for 50 cents; $\$ 2.00$ per dozen. 



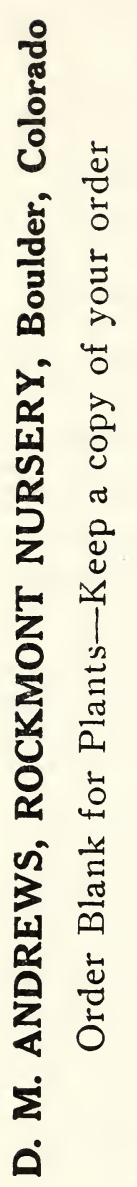

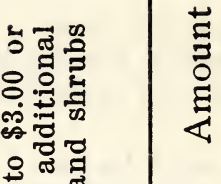

을

일

式 ญ ఖ

จู

ดี

䍏

त्र

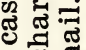

돈

룡요

용

엄

¿ै 4

$\frac{1}{3}$

解

ఊ

패용

.

죄

느ㅇㅝㅝ

되 है

पू

됙 ขै

웅

1 吹

車出

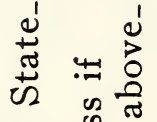

国 0 잉

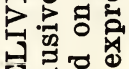

氠矛过

व य थ

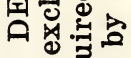

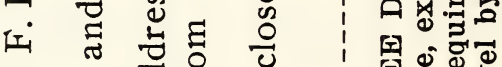

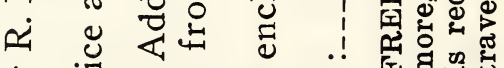

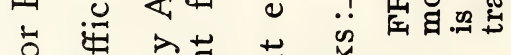

럼

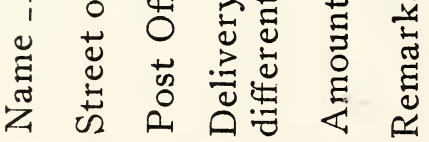

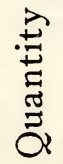

$\Xi$

Ð

范

눙. 몰

$\stackrel{\circ}{\circ}$ 

Lithospermum linearifolium. Puccoon. Long tubular phloxlike flowers of pale yellow on stems a foot tall. Three for 75 cents.

Lithospermum multiflorum. Gromwell. A low bushy perennlal, related to Mertensia, and has paniculate sprays of golden yel low bells in wonderful profusion. Grows on dry slopes and should have a well-drained sunny position. Three for 75 cents, $\$ 3.00$ per dozen.

Malvastrum coccineum. Scarlet Mallow. Low-growing, colonyforming plant for dry sunny slopes. The gray foliage and copperscarlet flowers in short terminal racemes afford a pleasing effect when planted in groups. Three for 50 cents, $\$ 2.00$ per dozen.

Mertensia ciliata, Mountain Bluebells. A luxuriant plant of graceful habit with fine glaucus foliage, the drooping sprays of pale blue flowers continue in bloom for a long period. Three for 75 cents, $\$ 3.00$ per dozen; Clumps, 50 cents.

Mertensia lanceolata. Prairie Bluebell. Grows in open dry fields and blooms in early spring. The delicate blue flowers appear first in a compact cluster which expands with the development of new flowers into an open panicle a foot in length. Three for 50 cents, $\$ 2.00$ per dozen.

Mertensia pratensis. A rare plant from the Spanish Peaks, green foliage and blue flowers. Clumps, 50 cents each.

Oenothera brachycarpa, Yellow Evening Primrose. Rosetteforming plant for lime-soil on dry slopes. Each rosette bears a succession of stemless 4 -inch flowers which age to orange-scarlet. Colony plantings are most effective. Three for 75 cents, $\$ 3.00$ per dozen.

Oenothera caespitosa, Tufted Evening Primrose. An exquisite rockplant for humus soil, forming large colonies on dry sunny slopes of loose granite soil. Quite similar in habt to the last, but with white flowers aging to rose. Plant in groups. Three for 50 cents, $\$ 2.00$ per dozen.

Pentstemon alpinus, Alpine P. Stocky, dwarf habit, the large dark blue flowers in a compact spike. An exceedingly beautiful and satisfactory rockplant. Clumps, 50 cents; smaller plants, $\$ 2.00$ per dozen.

Pentstemon angustifolius (Syn. coeruleus), Sky-blue P. Very dwarf and early, the sky-blue racemes carrying a tint of rose in the buds and flower tubes. Three for 75 cents.

Pentstemon humilis. Dwarf Blue Penstemon. Very easily grown in the garden and has proven everywhere one of the most successful. Very dwarf, the foliage forming mats of dark green, the flowers on 10-inch stems are intense blue. Clumps, 50 cents; smaller plants, $\$ 2.00$ per dozen.

Pentstemon lavendulus. This mountain form of secundiflorus is a smaller plant with narrower foliage and forms better clumps, bearing consequently more flowers. On a dry snnny slope it is very permanent and of excellent habit for the rock garden. Color is deep lilac-purple. Clumps 50 cents each; smaller plants, $\$ 2.00$ per dozen. 
Pentstemon saxosorum. A small plant with slender 10-inch stems and quite large flowers of dark blue-purple. It forms neat little clumps, has a good root system and promises to be longerlived than some others. A gem for the rockgarden with sun and drainage. Clumps 50 cents, three for $\$ 1.25$; smaller plants, $\$ 2.00$ per dozen.

Pentstemon secundiflorus. A distinct type with fine glaucus foliage, the stems a foot or more tall carrying a one-sided racemes of very showy lilac flowers. Grows along the foothills and requires dry conditions and full son. Clumps, 50 cents; smaller plants, $\$ 2.00$ per dozen.

Phlox multiflora. Dwarf Phlox. Mats of grayish foliage covered in early spring with lavender or lilac flowers. It grows on steep north slopes in a soil of decomposed granite and leafmold. Difficult to establish and offered without recommendation. Three for 75 cents, $\$ 3.00$ per dozen.

Primula Parryi, Parry Primrose. A very robust sub-alpine, a foot or more tall with rosettes of broad foliage producing large umbels of very showy crimson flowers with yellow centers. Moist humus or peat, acid soil, partial shade. Clumps, 50 cents; smaller roots, $\$ 3.00$ per dozen.

Rudbeckia montana. Coneflower. Dark purplish-black cones three or four inches long without rays is the unique feature of this Colorado species; 3 feet. Eeach 50 cents, three for $\$ 1.25$.

Salvia azurea. Azure Sage. If limited to one blue flower, it would be the Salvia in its several shades of blue. It never fails, thrives almost without care, is true blue and has a long season of bloom. Excessive moisture and fertility are to be avoided, as a rank growth results in loppy stems and inferior bloom. Clumps, 50 cents; flowering roots, \$2.00 per dozen.

Salvia Pitcheri. Dark-azure Sage. Later blooming and much darker blue, but otherwise identical with $\mathrm{S}$. azurea. The stems grow three feet tall and are well adapted for cutting. Try growing both Salvias in a rather dry position. Clumps 50 cents; flowering roots, $\$ 2.00$ per dozen.

Scabiosa caucasica. Blue Bonnet. The flowers of clear lavender-blue are borne in large heads on slender stems all summer; one of the few perpetual bloomers among hardy plants. A good cutflower. Clumps, 50 cents; flowering roots, $\$ 2.50$ per dozen.

Sedum Ewersii. Stonecrop. Handsome rock creeper with flat foliage and clusters of pink flowers in late summer. Clumps, 50 cents; $\$ 4.00$ per dozen.

Sedum integrifolium. (S. Rhodiola) Ruby Stonecrop. An alpine of the Colorado mountains for moist soil and partial shade. Forms neat little clumps, the low stems terminating in small clusters of dark ruby-red flowers which last a long time. Small clumps, 50 cents; $\$ 4.00$ per dozen.

Sedum Kamtchaticum. Orange Stonecrop. Broad-leaved creeper, foliage redish purple in winter; flowers deep golden yellow. Clumps, 50 cents; stron roots, $\$ 2.50$ per dozen. 
Sedum Maximowiczi. Amur Stonecrop. Frect stems a foot high with yellow flower's in broad terminal clusters. Clumps, 50 cents each; $\$ 3.00$ per dozen.

Sedum rhodanthum. (Clementsia lihodantha) Clement's Stonecrop. A native sub-alpine in moist soil and prefers half shade. Under best conditions it forms clumps a foot in height, with terminal clusters of pink fllowers. Clumps, 50 cents; strong roots, $\$ 2.50$ per dozen.

Sedum stoloniferum coccineum. Valuable cover plant for dry or sterile slopes, the fleshy leaves and stems reddening in autumn and winter, flowers amaranth-red. Clumps, 50 cents; strong roots $\$ 2.00$ per dozen.

Synthyris alpina. Alpine Kittentails. An easily-grown alpine from high peaks of the Colorado Rockies, for peaty lodm with half shade. It blooms very early, February to April, and seems quite indifferent to frost, often flowering in mid-winter during mild weather. Flowers in short silky spikes of blue or violet. Flowering clumps, 75 cents, $\$ 7.50$ per dozen.

Synthyris plantaginea, Kittentails. An attractive rockplant of easy culture, silky spikes of bluish flowers in early spring from a rosette of broad foliage. Clumps, 50 cents; $\$ 3.00$ per dozen.

Synthyris reniformis, Kidneyleaf. Round evergreen dentate leaves and violet-blue flower spikes in early spring. A charming plant for humus soil and shade. Clumps, 50 cents; $\$ 3.00$ per dozen.

Synthyris rotundifolia, Roundleaf. Same culture and rosette forming habit as reniformis, the flowers light blue in smaller but more numerous spikes, often during mid-winter in mild weather. Clumps, 50 cents.

Trollius albiflorus, White Globeflower. A desirable sub-alpine for a moist peaty soil in partial shade. It blooms early, the flowers quite large, sulfur, fading to pure white. Clumps with several flowering crowns, 50 cents each, $\$ 3.00$ per dozen.

Trollius Europeus. Globeflower. Exquisite plant for partial shade, the half-opening flowers clear yellow. Each 50 cents, three for $\$ 1.50$.

Valeriana acutiloba, Valerian. A very charming alpine or rockplant which will thrive under ordinary garden conditions. Forms a nearly evergreen leafy tuft, producing a succession of flowering stems from very early spring till June, and often in autumn. The small white or rose-tinted flowers are disposed in rather close heads and the plant resembles a miniature Gardenheliotrope. A rigidly tested novelty of exceptional worth. Clumps, 50 cents each; $\$ 3.00$ per dozen.

Valeriana micrantha. A little taller than acutiloba and the flowers creamy-white, in a more compact cluster. Both are attractive and distinct. Each 50 cents, three for $\$ 1.00$.

Viola rugulosus, White Violet. A magnificent species with large foliage and large white flowers. Clumps, 50 cents; three for $\$ 1.00$. 
Yucca coloma, Soaproot. Best of all the yuccas for the rock garden because of its small size, it is proving to be in the East a most satisfactory grower, originating as it does in a climate of more abundant rainfall than the desert types. With its miniature rosettes of stiff blue-green foliage and slender flower spikes, no hardy species is more beautiful. Strong established plants. $\$ 1.00$ each, three for $\$ 2.75$.

Yucca filamentosa variegata. Of two or more variegated yuccas, this narrow-leaved type is entirely hardy and is a thrifty grower. The leaves have very narrow stripes of green and creamy white in summer, but in winter the white stripe becomes strongly tinged with red and is then the most beautiful variegated plant I have ever seen. Strong field-grown plants, 75 cents each, three for $\$ 2.00,10$ for $\$ 6.00$.

Zygadenus elegans, Star Hyacinth. A lilaceous plant for moist soils with slender stems and racemes of white flowers. Clumps of 3-5 pips, 50 cents.

Zygadenus gramineus, False Camas. Rosette of grasslike foliage from a bulb. with spike of lilaceous flowers of creamy white in early spring; dry sandy soil, sun. Three for 50 cents.

\section{Iris Introductions}

As a grower of fine Iris it has become my policy to maintain an experimental collection of the most promising new varieties and the older varieties of accepted worth, both American and foreign. These are retained for observation and breeding until superceded. At no time do I possess anything like a complete collection of Iris varieties, nor do I list any at present in my retail catalogues, save only my own introductions. Any sumplus is disposed of to commercial growers.

Although my own introductions have been comparatively few, those which have been rated show a high average of points. This may be accounted for as follows. First, very few iris seeds are saved and planted without a recorded pedigree of both parents. Second, no inferior iris variety is permitted to become a parent. Third, no inferior seedling is allowed to remain after flowering, but is immediately uprooted and destroyed. This minimizes confusion and uncertainty in the proving of varieties for final trial. Fourth, only outstanding varieties ever pass the final trial, and my standards of merit become more rigid each season. Visitors are welcome always to inspect my plantings and judge the results of such a policy.

In presenting a few new varieties for 1931, my own valuations have been checked by other growers who have seen them when in bloom. None of the 1931 introductions is believed to displace any existing variety. Except for occasional pet antipathies as to color, I predict a liberal rating by those who become sponsors for my originations in their own gardens.

Desert Dawn. Andrews, 1931. O-25. (Candlelight x Amerind). With something of the glory of a cloudless sunrise at the rim of the desert, this seedling of Candlelight surpasses its parent in 
the effect of radiant illumination. A glorious yellow blend, retaining small areas of pure lavender in the tips of both standards and falls. Flowers of very large size, durable substance and splendid form, held well aloft on 42 -inch stems which are erect but freely branched. The habit of growth and the excellent spacing of the flowers makes the clump-effect ideal for symmetry and freedom of bloom. Quite unlike Candlelight and does not displace it. Offered for delivery, July, 1931. Price \$25.00; reservation upon deposit of one-fourth the price.

Gilead. Andrews, 1931, N-15. (Candlelight x Amerind). A golden yellow-bronze, self-blend. Ground-color, deep colonial buff, with an overlay of amber, only slight deeper in the falls. Flower very large with high arching standards; 42-inch stems, well branched and free flowering. Name from the crystalline amber gum coating of the winter buds of the Balm of Gilead tree. Offered for delivery, July, 1931. Price $\$ 20.00 ;$ l'eservation upon deposit of one-fourth the price.

Mountain Mist. Andrews, 1931, M-6. (Candlelight x Amerind). Pale mauve-bronze, approaching gray. Its even tone suggests the bluish haze on distant hills at nightfall. A delicate pastel tint which does not fade in our bright sunlight. Large flower of ideal form on 40-inch stems. Delivery, July, 1931. Price \$10.00; reservation upon deposit of one-fourth the price.

Rusty Gold. Andrews, 1931, M-2 (Seedling 94 x Amerind). Orange-bronze blend; like tarnished gold, with a flush of copper in the falls. Vivid coloring of intense carrying quality, very tree flowering. Medium sized flower of exceptionally fine form and substance on a well proportioned plant; a landscape variety of magnificent promise which propagates freely. Delivery, July, 1931. Price $\$ 15.00$; reservation upon deposit of one-fourth the price.

\section{Earlier Introductions}

The highest rating of any Iris in the last Symposium of the American Iris Society was given to Candlelight, 96. Odaroloc received 90. I take great delight in the flowering of Candlelight each season and I am sure it will long continue to be a favorite. The price this year will permit many to have it who have not grown it before.

Among my earlier introduction, do not overlook Odaroloc, the best bloomer and finest grower in the class of mauve or pink-toned lavender selfs. For sheer whiteness and cliarming form, Alabaster has not been surpassed. Larger size would be desirable, but without purity of tone the appeal of size is not convincing. For breeding, Amerind lends lieight and a sturdy constitution. Its offspring often show large size of flower and unexpected color traits. Jackrose has exceptional color, the deepest and richest tone of the pallida reds. It is tall, vigorous and free.

Alabaster. Andrews, 1926. Pure white flower of medium size, exceptionally fine form, very free bloomer. Price $\$ 1.50$ each for July or August delivery. 
Amerind. Andrews, 1926. Metalic bronze, the standards slightly more golden than the falls. Tall, freely branching, good substance. Price $\$ 1.50$ each for July or August delivery.

Candlelight. Andrews, 1926. Pale pinkish lavender, illuminated from within with a rich golden glow, suggesting the name. Vigorous grower to nearly four feet. Price $\$ 2.00$ each for July or August delivery.

Jackrose. Andrews, 1929. Color deep redish purple the best in its class for color, substance and constitution. Vigorous, free, and over three feet tall. Price $\$ 2.00$ each for July or August delivery.

Odaroloc. Andrews, 1924. Pure light mauve with a suffusion of pink. Flower large, well arched with flaring falls on stems nearly four feet in height. A most prolific bloomer. Price $\$ 1.00$ each for delivery July or August.

\section{Candlelight Iris Collection}

To make it possible for every Iris grower to possess free of cost the highest-rated Iris of the Iris Society Symposium, I am offering my Candlelight Collection. It will include one root each, No. 1 grade, Alabaster, Amerind, Candlelight Jackrose and Odaroloc, which would cost $\$ 8.00$ of bought separately; and the collection will be delivered prepaid in July or August, 1931, for $\$ 6.00$. You can have additional collections all to one address or to separate addresses, at the same price. As my stock of Jackrose is limited, it is advised to order at once the number of sets desired, sending your remittance last of June if more convenient. Note that Candlelight is included free in the price of the collection.

\section{New Introductions in Phlox}

The six varieties of Phlox offered below include four exceptionally brilliant bits of color. The four are Mendelian hybrids derived from Coquelicot, into which large size has been introduced, together with greatly improved habit and constitution. Osceola, Snowcap and Tanager have florets larger than a silver dollar. Silverton much larger and Colorado approaches closely. Robin Hood is of medium size but larger than others of its color class. Introduced last season, except Silverton, which was introduced in 1927. One root each of the six for $\$ 6.00$ delivered, prepaid.

The prices are for strong field-grown roots, sold singly as follows:

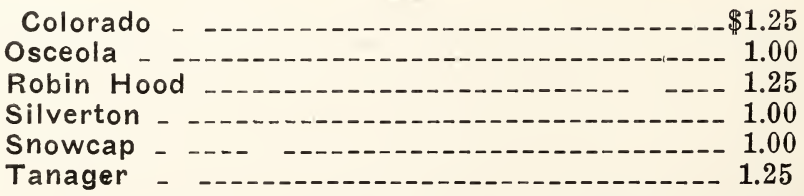

Note. See fall catalogue for description of Phlox introductions. Copy mailed on request. 


\section{Hardy Lilies}

Hardy Lilies for the garden are one of my important specialties. More than 100,000 bulbs are in stock. The cool mountain climate and ideal soil conditions with exceptional care in growing are responsible for firm heavy bulbs of large size with no trace of disease. None are kept in storage, as I believe fall planting to be best. All are ready for delivery in early autumn before the imported bulbs arrive. The following varieties will be available next fall.
Lilium Candidum
Lilium bulbiferum
Lilium elegans aureum (robustum)
Lilium elegans quilp
Lilium elegans aurantiacum
Lilium elegans Horsmannii
Lilium pardalinum
Lilium Henryi
Lilium tenuifolium
Lilium Sargentiae
Lilium tigrinum splendens
Lilium tigrinum fl. pl.
Lilium umbellatum hybrids
Lilium umbellatum

\section{Plant Collections}

The following plant collections are mainly suggestive to those who are interested more in "Delightful Flowers' 'than in botanical relationships. In ordering it is only necessary to name the collection; for example, "Miniature Shrub Collection," without listing the items. The economy in assembling and labeling several collections, all alike, is passed on to the customer in the form of a price reduction. For this reason no changes are permissible in any of the collections, except that the latest catalogue will always govern. The plants of every collection are labeled, and I guarantee safe delivery. See alphabetical lists for descriptions. Each planting unit or clump to have a minimum value of 50 cents.

\section{Miniature Shrub Collection}

Miniature shrubs to fit the rock garden do not constitute a large list and the following collection is eminently suitable for the purpose. All but Caragana and Lonicera are native to Colorado. The prices include delivery prepaid, but somewhat heavier stock will be supplied if purchaser pays transporation. One each prepaid for $\$ 5.00$; three each prepaid for $\$ 14.00$. as follows:

Amorpha canescens Betula glandulosa Jamesia Americana
Amorpha nana

Caragana aurantiaca

Lonicera Thibetica

\section{Rock Garden Collection}

A dozen easily grown rock garden plants, all from the Colorado mountains, and suitable for a moderately dry rock garden, neutral to moderately acid soil, in full sun; except that two items, Sedum rhodanthum and Zygadenus elegans prefer more moisture. One plant or clump of each delivered prepaid for $\$ 5.00$; three plants each delivered prepaid for $\$ 14.00$; twelve plants each, not prepaid, for $\$ 50.00$; as follows: 
Clematis Scottii

Geranium nervosum

Liatris punctata

Pentstemon humilis

Sedum rhodanthum

Valeriana acutiloba

\author{
Erigeron Coulteri \\ Leucocrinum montanum \\ Lithospermum multiflorum \\ Pentstemon humilis \\ Synthyris plantaginea \\ Zygadenus elegans
}

\section{New or Noteworthy Collection}

This offering should be extremely popular because it includes noteworthy plants most commonly ordered, and the price reduction is liberal. The twelve plants or clumps will be delivered prepaid, one each, for $\$ 5.00$; three each prepaid for $\$ 14.00$; twelve each, not prepaid, for $\$ 50.00$; as follows:

\begin{abstract}
Anchusa myostidiflora
Convallaria (Parsons Var.)

Dodecatheon media

Iris Mo. Bluebird

Rudbeckia montana

Sedum maximowiczi
\end{abstract}

Centaurea rigidifolia

Clematis recta grandiflora

Dryopteris Filix-mas

Mertensia ciliata

Salvia Pitcheri

Yucca fil. variegata

\section{Lovelier Lilac Collection}

No need to wait till Prosperity calls to knock at your door! This superb offering should prove irresistible. Four splendid French Hybrids, selected for color and dependability, together with the very late-flowering lilac, Syringa villosa. Read the descriptions under "Lovelier Lilacs." The five are supplied in thrifty young established bushes, not grafted, but on their own roots, and will be delivered prepaid for $\$ 5.00$. Larger bushes, the same varieties, purchaser to pay express charges, will be furnished at the same price, $\$ 5.00$; as follows:

Charles Joly

Mme. Casimir Perier
Congo

President Grevy

\section{Late lilac, Villosa}

\section{Hardy Cactus Collections}

In Colorado are various species of cactus which are perfectly hardy to any degree of cold, provided they are grown dry enough during the autumn months, so that they go into winter with tissues somewhat shrunken.

Given a dry rockery in full sun, a slope, or the edge of a terrace with soil texture to facilitate drainage, and the reward of gorgeous flowers in early summer is almost inevitable.

I have hesitated in offering cactus plants for the reason that they cannot be packed conveniently with other stock; and, second, because they are apt to be called for at any and all seasons. Please bear in mind, that I am not a cactus grower; do not have them in stock. But I propose to collect fresh plants, in March only, not later, and supply collections to include both the prickly-pear type of Opuntias and cylindrical Echinocereus, etc., all correctly labeled, properly packed to insure safe delivery and sent prepaid for $\$ 5.00$.

Your order must be reeived before the end of March for the reason that there is no time in April to collect and make up 
these collections. You may, however, order in March and have the collection packed and set aside in our cool cellar for de. livery at any date up to May 1st.

Note. Cactus collections may be ordered for August delivery, and orders received too late for spring delivery will be filled in August, unless I am advised otherwise. Cactus plants are soft and easily injured in midsummer and no deliveries will be made then.

Hardy Cactus Rock-garden Collection will include about forty (40) cactus in six or more varieties, all labeled. There will be rooted cuttings of Opuntia and assorted plants of Echinocactus and Echinocereus. All are hardy and suitable for the rock-garden, and some will be small enough for dish-garders. Price prepaid, \$5.00; none sold less than full collection.

Hardy Cactus Dish-garden Collection will include small forms only of about four varieties which are suitable for use in the planting of dish-gardens. This collection is intended for florist's use, and will contain 75 cacti prepaid, consisting of miniature Opuntia cuttings and small plants of Echinocereus and Echinocactus, delivered for $\$ 5.00$. If purchaser pays transportation, one or more collections may be ordered at the same price to include 100 plants each.

\section{Seeds of New or Noteworthy Plants}

Very good results are reported in growing mountain flowers from seed. True of these as of other perennials, the germination is not always regular and prompt, but many of them will appear quickly and not rarely will flower the first year. On the other hand, some perennials have a period of dormancy after planting, of a few weeks or months up to a year or longer. For this reason fall planting in frames is quite practical, allowing as it does, the dormant period to include the winter months with the farther advantage that winter conditions in the ground are ideal for a vigorous start in the spring. Nearly the same advantage results from planting in flats late in the winter and then subjecting them to freezing and snow in late February and March. A few obdurate kinds after all this will take theil own time, and instead of germinating in the spring after planting, will (if kept under favorable conditions) appear with great vigor a year later.

Those who are not gifted with a good degree of patience are advised to start with plants whenever practicable, as the seedling are prone, even after" germination, to "make haste slowly".

Seed prices. Seeds of the following named valieties, where no price is printed, are put up in packets at a uniform price of 25 cents per packet. A few scarce items, priced at 50 cents per packet, are included in the list. Seeds offered by weight are also sold in packets. The minimum order for seeds is $\$ 1.00$.

Non-warranty. I supply seeds which I believe to be of sound quality and able to germinate under proper conditoins. They are 
sold at a nominal price. Successful culture depends upon conditions not under my control. Upon these considerations, please do not ask for replacement or reimbursement in case of failure.

Anemone globosa. Red, Anemone or Windflower. A sub-alpine for a gritty, peat soil, acid, with part shade. Packet 50 cents.

Anemone patens Nutt. American Pasqueflower. Silky buds in spring expand into showy flowers of pale lilac.

Anemone pulsatilla rubra. The dark red form of the European Pasque-flower; true from seed. 50 cents per packet.

Aquilegia coerulea. _Rocky Mountain Columbine. Four-inch blossoms of blue and white with long spurs. $1 / 4$ ounce $\$ 1.00$.

Aquilegia hybrida, Rainbow Blend. Rainbow Columbine. Surpasses other hybrid strains in variety and brilliancy of coloring and in the predominance of colorful shades of pink, rose, scarlet, velvety reds and purples. $1 / 4$ ounce $\$ 1.00$.

Argemone hispida. Dwarfest of the Prickly Poppies with large white flowers of satiny texture and bluish green foliage.

Aster ptarmicoides. (Western form.) White Aster. An excellent rock plant a foot tall for dry soil and full sun. Good foliage and neat sprays of pure white flowers of lasting substance for cutting.

Astragalus Shortianus. Bright purple flowers from a rosette of pinnate foliage, appearing in early spring; dry sunny position.

Campanula petiolata. Western Harebell. The blue bells on slender stems are borne in utmost profusion for a long season.

Clematis Orieintalis. Yellow Clematis. (Vine.)

Clematis recta grandiflora. Magnificent clumps, foliage finely cut, dark green, each stem producing 25 or more fragrant white flowers two inches across.

Corydalis montana. Golden C. Profusely blooming annual forming low mats for filling spaces in the rock garden.

Delphinium elongatum. Tall mountain Larkspur to four feet, with very long racemes of grayish-blue flowers, easily grown. Packet 50 cents.

Delphinium Geyeri. Geyer Larkspur. Grayish foliage, slender spikes of intense blue; dry, sunny position.

Delphinium subalpinum. Forms massive clumps to four feet with stout stems and dense racemes of dark blue, new. Packet 50 cents.

Dodecatheon media. Shooting Star. Not difficult from seed but develops slowly.

Dodecatheon multiflorum. Valuable sub-apline, for moist position. Packet 50 cents.

Erysimum asperum. Western Wallflower or Yellow Phlox. An easily grown annual with yellow or orange phlox-like flowers on foot-high stems. 
Gentiana Bigelovii. Bigelow's Gentian. Many-stemmerl rock plant for sunny slope in medium to heary peaty loam. Flowers bright blue, in clusters.

Gentiana elegans. Western Fringed-gentian. Deep azure blue fringed flowers; biennial, growing in wet sub-alpine mearlows

Gilia pulchella. Bush Cypress or Skyrocket. A choice hiennial for gravelly, peaty soil, preferably a sunny slope. Beginning early the second season the scarlet, pink or white starlike flowers are produced on yard-high stems all summer.

Harbouria trachypleura. Golden Parsley. Slender stems with foliage delicate as a fern, and showy umbels of golden flowers; a valuable rockplant for a dry sunny place.

Helenium Hopesii. Sub-alpine daisy with large orange flowers on 20-inch stems; orginary soil.

Heydysarum pabulare, Jointpod. Sprays of rosy pink pea blossoms on stems a foot tall; dry limestone slopes.

Helianthella quinquenervis. Sunwort. Early flowering composite with tall slender stems and yellow-rayed flowers.

Iris missouriensis. Blue-flag. Native spring-flowering iris of pale blue. $1 / 2$ ounce, $\$ 1.00$.

Lepachys columnaris. Coneflower. A gem for the rork gardon or low border, yellow drooping rays and dark cones.

Lepachys columnaris pulcherrima. Painted Coneflower. Out standing for its remarkable color. Identical with the yellow form except that the rays are a rich mahogany-red; blooms true from seed.

Liatris ligulistylis. Rocky Mountain Gayfeather. Dwarf, early species with very large heads of rosy magenta.

Lilium pardalinum. Leopard Lily. One of the best and most easily grown western lilies.

Lilium Parryi. Parry's Lily of California, for a deep soil rich in humus with slight shade. Packet 50 cents; 1/4 ounce, $\$ 2.00$; ounce, $\$ 7.50$.

Lilium tenuifolium. Corral Lily.. Scarlet bells with jecurved tips, easily grown and flowers quickly from seer. 1/4 ounce $\$ 1.00$; ounce, $\$ 3.50$.

Lilium Washingtonianum. Tall west-coast lily, flowers white, spotted purple, fragrant. Packet 50 cents.

Lupinus argenteus. Pluebonnet. Two feet, showy blue spikes, deep well-drained soil.

Lupinus decumbens. Lupine. Three feet much branched lilas, free bloomer for a long season.

Lupinus Plattensis. Bicolored Lupine. Remarkable for the conspicuous blotch in the upper half of each flower; rare lowgrowing species. 
Mentzelia decapetala. (M. ornata.) Evening Star. Marvelous five-inch, ten-petaled stars of creamy white, opening late afternoon for several weeks; perennial in dry calcareous soil.

Oxytropis campestris. Hybrid Loco. Wisteria-like spikes a foot in height from a rosette of silvery, pinnate foliage; wide wide range of color; rose to crimson, lavender to purple and white. All species of Oxytropis thrive easily in a warm, sunny place in a well-drained loam, and are ideal for the rock garden.

Oxytropis Lambertii. Crimson Loco. Many spikes of crimson pea blossoms from a rosette of pinnate foliage.

Oxtropis villosus. Silky Loco. Silky-gray rosettes and creamy flowers.

Pentstemon albidus. White Pentstemon. A low-growing native of sandy plains, easily grown and rather more permanent in cultivation than others. Flowers white.

Pentstemon angustifolius. (P. coeruleus.) Dwarf, early, skyblue flowers, tinted rose.

Pentstemon alpinus. Easily grown alpine with compact spike of deep blue.

Pentstemon ambiguus. A low, branching rock garden type with many flowers of white or pink, dry plains. slopes.

Pentstemon humilis. Quite dwarf, deep blue, sunny rocky

Pentstemon grandiflorus. The most magnificent of truly hardy Pentstemons; Black Hills to western Nebraska and Kansas, on the plains. Two or three feet tall with immense trumpets of rich violet-purple. Liberal packet 50 cents; one-eighth ounce $\$ 1.00$.

Pentstemon stenosepalus. A foot tall, large deep purple flowers.

Pentstemon unilateralis. Tall, deep purple flowers in long racemes.

Picea pungens glauca. Colorado Blue Spruce. Sown in the spring in a frame or bed shaded with lath or muslin, the Blue Spruce can be grown from seeds, and my select blue strain will give a good percentage as blue as grafted specimens, and nearly all will be of the blue type. XX grade seed, $1 / 4$ ounce $\$ 1.00$; ounce $\$ 3.00 ; 1 / 4$ pound $\$ 10.00$.

Polemonum confertum. Musk-flower. A treasure among Colorado alpines, forming clumps at high altitudes, the very conspicuous flower clusters reflecting the intense blue of the alpine sky.

Polemonium melitum. Polemonium. Similar to P. confertum except in color of the flowers which are sulphur-white. Easily grown in light soil and partial shade.

Polemonium occidentale. Belongs to a distinct group of this genus, producing violet blue bells for a long season on 12-inch stems. Easily grown in humus soil in half shade. 
Polemonium robustum. Two feet tall, long season of blomm,

Primula Parryi. Parry's Primrose. Large umbels of (rimson flowers from a rosette of light green foliage.

Quincula lobata. Low rock plant for dry, sunny spot, with purple star-shaped flowers.

Rudbeckia hirta. Brown-eyed Susan. Easily-grown perennial with golden-yellow rays and dark center.

Salvia azurea. Azure Sage. Light blue; ounce \$2.00.

Sedum stenopetalum. A low tufted plant with minute foliage for dry sunny rockery, thickly set with golden stars suffuserl red Packet 50 cents.

Sidalcea neo-mexicana. Mountain or Rose Mallow. A plant of neat habit from high mountain meadows with slender branch. ing inflorescence, and flowers like miniature hollyhocks well over an inch broad, of clear rosy pink. One-eighth ounce \$1.(00.

Thermopsis montana. Buffalo Pea. A foot high, early spring, showy yellow pea blossoms.

Thermopsis rhombifolia. Very dwarf species; yellow.

Trifolium dasyphyllum. Alpine Clover or Trifoil Tufts of narrow foliage from a deep root, not creeping, and lieads of showy pink flowers. A lovely alpine for rock crevices.

Trifolium Parryi. Parry's Alpine Clover. Of similar habit. foliage broader and the large flower heads deep rosy purple, very beautiful.

Trillium sessile Californicum. The large white Trillium of California; hardy. Packet 50 cents.

Wyethia amplexicaules. Very showy, large flowered composite of the high mountains in moist ground, a foot or two tall.

Yucca glauca. Soapweed. One of the hardiest and easily grown from seed.

Zygadenus gramineus. A liliaceous plant with creamy flowers from a deep bulb, dry sandy soil, full sun. 
